\title{
Unpacking the Relationship between Outward Direct Investment and Innovation Performance: Evidence from Chinese Firms
}

\author{
Xiaolan Fu \\ TMCD, Department of International Development, University of Oxford, Email: xiaolan.fu@qeh.ox.ac.uk \\ Jun Hou \\ International Business School, University of Lincoln, Email: jhou@lincoln.ac.uk \\ Xiaohui Liu \\ School of Business and Economics, Loughborough University, Email: X.Liu2@lboro.ac.uk
}

\begin{abstract}
This study investigates the impact of outward direct investment (ODI) by Chinese MNEs on innovation performance and the conditions under which such an impact is moderated, based on a sample of Chinese firms. The empirical evidence suggests that undertaking ODI leads to an increase in the innovation performance of these Chinese firms. The impact of ODI on innovation is contingent on firm characteristics such as in-house $R \& D$, strategic orientation and international experiences as well as contextual factors associated with investment destinations and industry contexts. We also find that learning through ODI is a complex process. There is a substitution between ODI and in-house R\&D in Chinese MNEs. Our findings suggest that conducting ODI in developed countries serves as an effective channel for latecomer firms to overcome internal resource constraints and leapfrog towards the technology frontier.
\end{abstract}

Keywords: ODI in developed countries, learning, innovation performance, Chinese MNEs 


\section{Introduction}

Outward foreign direct investment (ODI) is widely recognized as an important internationalisation strategy by firms from developing countries. To achieve a sustainable growth, developing countries, especially emerging economies (EEs), have actively invested in developed economies in order to access key strategic assets, resources and leading-edge technologies (Liu and Buck, 2009; Luo and Tung, 2007; Ramamurthi and Singh, 2009). Unlike MNEs from developed economies that normally adopt technologically advanced production, emerging market multinational companies (EMNEs) typically consider different investment motives due to the lack of advanced technologies, marketing techniques, and established brands (Lall, 1992; Narula, 1996; Li, 2007; Luo and Tung, 2007). Although both developed and developing country firms employ ODI as a means of international expansion, the differences in firm-specific advantages and investment strategic orientations between the two types of firms raise questions as to whether previous findings derived from advanced country MNEs are applicable to EE firms (Buckley et al., 2007; Boisot and Meyer, 2008; Sun et al., 2010; Deng; 2012).

Despite recent calls for more research on the internationalisation of ODI from EEs, most studies focused on the EMNEs' motives (Child and Rodrigues, 2005; Luo and Tung, 2007; Witt and Lewin, 2007), location choices (Lu et al., 2014) and entry selections (Cui and Jiang, 2012; Morck et al., 2008; Wang et al., 2012; Cozza et al., 2013). With respect to the outcomes of ODI activities, great emphases have been placed on the impact of ODI on profitability (Chari et al., 2012), productivity (Cozza et al., 2013) and trade (Chen and Tang, 2016). Yet, little is known about the extent to which ODI contributes to the innovation performance of EMNEs and especially under what conditions ODI acts as an effective channel of enhancing innovation (Chen and Tang, 2016). Our understanding of the boundary conditions in leveraging the relationship between ODI and the innovation performance of EE firms is limited. This study aims to address this gap by focusing on the interplay between firm heterogeneity, contextual factors and ODI in relation to the innovation performance of EMNEs.

The rapid increase in ODI from China represents an interesting case for this study. The total ODI made by Chinese firms exceeded 77.2 Billion USD in 2012, which was an increase of about 2.5 times compared to the value in $2007 .{ }^{1}$ In the ODI ranking list, China has moved up to third place, after the United States and Japan. Yet the technological gap between China and

\footnotetext{
${ }^{1}$ Data source: National Bureau of Statistics of China. http://data.stats.gov.cn/index.
} 
developed countries remains significant. The majority of Chinese MNEs (CMNEs), except for a small number of firms like Huawei or ZTE, are still followers in innovation $(\mathrm{Fu}, 2015)$. Chinese ODI therefore serves as an ideal setting to examine the relationship between external knowledge sourcing through ODI and innovation performance in the context of EEs.

This study contributes to the literature in the following areas. Firstly, based on a sample of 189 firms from Guangdong province from 2007 to 2009, we investigate whether and under what conditions ODI yields a positive impact on the innovation performance of Chinese investing firms. A recent study by Chen and Tang (2016) revealed the positive association between ODI and firm performance, including $\mathrm{R} \& \mathrm{D}$ and new product sales, based on a cross-sectional sample of ODI deals from China. The current study is distinguished from that of Chen and Tang (2016) by not only testing the direct association between ODI and the innovation performance of Chinese firms, but also by unpacking the boundary conditions under which ODI has an innovation-enhancing effect. More specifically, we differentiate ODI according to the type of destinations - developed or developing countries and their industries, such as hightech and low-tech industries. Such differentiations enable us to provide new insights into the contexts in which external learning via ODI takes place from a learning perspective and provide empirical evidence. Our findings show that Chinese ODI in developed countries serves as an 'innovation springboard' for latecomer firms to overcome internal constraints and leapfrog towards the technology frontier. While strategic asset seeking has long been regarded as a major motivation for ODI, especially for MNEs from developing countries, there is a lack of empirical evidence on whether these MNEs have achieved their strategic objectives. Our empirical findings thus help address this research gap.

Secondly, this paper intends to reveal what lies behind the relationship between ODI and the innovation performance of CMNEs by examining the extent to which the innovation-enhancing effect of ODI is also contingent on firm characteristics such as in-house $R \& D$, strategic orientation and international experiences. The findings from this research shed light onto the interrelationship between internal learning in the form of in-house $R \& D$ and external learning via exporting and ODI. Learning through exporting and ODI is complementary and jointly contributes to the innovation performance of CMNEs, whereas ODI in the high-tech industries serves as an effective knowledge source to overcome weak internal R\&D capabilities. Our research extends the organisational learning theory by capturing a more complex learning 
process experienced by EMNEs. Finally, the panel data used in this study allows us to adopt techniques to remove the potential estimation bias, thus providing reliable empirical evidence.

The rest of the paper is organised as follows. Section 2 discusses the theoretical background and develops the hypotheses. Section 3 describes the methodology for empirical tests. Section 4 presents the estimation results. Section 5 presents the conclusions.

\section{Theoretical background and hypotheses}

\subsection{External learning, outward direct investment and innovation}

We adopt a learning perspective to examine the extent to which ODI as a means of external learning allows firms to enhance innovation by acquiring international knowledge. Organisational learning is concerned with access to knowledge and the capabilities needed for creation of new knowledge and places great emphasis on knowledge acquisition (Levitt and March, 1988; Huber, 1991; Hurley and Hult, 1998; Gao et al., 2008; De Clercq et al., 2012). In particular, externally sourced knowledge is crucial to the learning process in which organisations can combine internal and external knowledge from outside their firms' boundary to create new knowledge. Thus, a firm's ability to exploit external knowledge is crucial to its innovative capabilities and determines the commercial success of its innovation (Cohen and Levinthal, 1989; Cassiman and Veugelers, 2006; Lokshin et.al., 2008). It is noted that learning also relies on the development of a stock of prior knowledge which is mainly achieved through in-house R\&D investment. The incentive to learn also influences a firm's innovation. While these insights derived from organisational learning help underpin the impact of ODI by latecomer MNEs from EEs, they overlook the boundary conditions through which learning takes place, as well as the interrelationship between internal learning through conducting inhouse $R \& D$ and external learning through ODI. Our study aims to extend the organisational learning approach by specifying the conditions under which learning via ODI contributes to innovation performance in the context of EMNEs about which our understanding is still limited.

Johanson and Vahlne $(1977,1990)$ suggest that learning and knowledge accumulation can be effectively achieved through the internationalisation process, and more international activities lead to more knowledge exploration (Pearce, 1999; De Clercq et al., 2005). Overseas investments create great learning potentials, expose companies to diverse knowledge environments and help them to enhance their knowledge stock (Meyer et al., 2009; Ghauri and 
Park, 2012). During the course of internationalisation, external knowledge acquisition can take place via product specification, quality standard requirement, interaction and collaboration with foreign firms and other institutions.

ODI has been acknowledged as an effective way to enhance innovation capability because it not only offers companies the opportunities to get access to foreign codified knowledge as trade does, but also facilitates the transmission of tacit know-how by spatial proximity, social embeddedness and mobility of skilled workers (Polanyi, 1966, 1967; Uzzi, 1997; Dhanaraj et al., 2004; Narula and Santangelo, 2009). This tacit knowledge not only plays a key role in the development of innovation, but also can effectively assist in the acquisition and transmission of codified knowledge (Uzzi, 1997).

To achieve competitive advantage and overcome latecomer disadvantages on the global stage, CMNEs have rapidly expanded their overseas investment, penetrating the market previously dominated by established Western MNEs (Zhang et al., 2010; Peng, 2012; Gu and Reed, 2013). Not only by acting in a conventional way to seek new markets, ODI has also served as a strategic asset-seeking channel for exploiting learning opportunities and building innovation capabilities (Child and Rodrigues, 2005; Mathews, 2006; Luo and Tung, 2007). Empirical studies have shown that firms actively engaging in cross-border investment generate more knowledge than those operating only in the domestic market (Kuemmerle, 1997; Lyles and Dhanaraj, 2004; Keller, 1997; Driffield and Love, 2007; Pittiglio et al., 2009; Fu, 2012).

In recent years, CMNEs have extensively engaged in strategic asset-seeking activities in advanced countries to acquire innovation resources through ODI (Wang, 2002; Deng, 2007; Burghart and Rossi, 2009). Thus, ODI is regarded as an effective practice to catch up with the technological frontiers and overcome the lack of advanced technology in their home country (Child and Rodriguez, 2005; Liu et al., 2005; Liu and Buck, 2009). Several studies show that Chinese ODI presents distinctive contrasts from that of developed countries regarding investment motives and host country contexts in which they operate (Buckley et al., 2007; Wang et al., 2012; Cozza et al., 2013; Cui et al., 2013). Although factors such as destination of ODI, strategic orientation, international experiences and in-house R\&D are not uncommon in the literature on innovation and internationalization, they are under-researched in the literature concerning the impact of ODI on investing firms. For example, Cozza et al. (2013) have investigated the impact of ODI on Chinese firms' performance and uncovered that participating in ODI enhances productivity and efficiency of these firms. Chen and Tang (2016) 
have found that undertaking ODI significantly promotes export and import volumes. Yet few studies have explored the innovation gains by ODI. Compared to MNEs from advanced economies, CMNEs lack advanced technology and suffer late mover disadvantages in global competition (Child and Rodrigues, 2005; Mathews, 2006; Buckley et al., 2007; Luo and Tung, 2007; Marin and Bell, 2010). Enhancing innovation through ODI does not accrue automatically and requires CMNEs to exert continuous effort to explore host-country resources via various channels (Dunning, 1988; Niosi, 1999; Fagerberg, 2005), as well as to build up compatible absorptive capacity to facilitate reverse knowledge flows (Cohen and Levinthal, 1989). Such a learning process also involves the presence of contextual factors, including the knowledge environment of a host country and industry dynamics, and certain firm characteristics, such as firms' strategic orientation, absorptive capacity and past experiences (Levitt and March, 1996; Jerez-Gomez et al., 2005).

\subsection{Destination-country technology advancement, strategic orientation and CMNE innovation}

Countries vary in their knowledge stocks and innovation activities due to differences in their innovation systems and the level of R\&D investment (Furman et al., 2002). Cross-country differences in technology advancement motivate laggard firms to expand internationally via ODI to access new knowledge and skills (Cantwell, 1989; Luo and Tung, 2007). The intrinsic characteristics of ODI offer technology followers from EEs an opportunity to obtain complementary assets (Ghauri and Park, 2012). Investing in developed countries allows CMNEs to gain proximity to technology leaders. By fully embedding in a foreign market, upto-date technologies become accessible via direct acquisition, various linkages, and mobility of assets. It also allows them to directly exploit and absorb the locally embedded managerial competences and invaluable skills that are otherwise not available in their home markets (Levitt and March, 1988; Nelson and Winter, 1982). In addition, it is commonly recognised that the quality standards are in general higher in developed countries than in developing countries (Kim, 1998; Sachwald, 2001; Athreye, 2005). Higher requirements from the market demand, together with the fierce local competition, will push CMNEs to innovate. Hence, conducting FDI in developed countries enlarges CMNEs' strategic assets' stock and opens a technological capability-upgrading trajectory, which in turn will enhance the innovation performance of CMNEs. 
Hypothesis 1a: CMNEs' ODI in developed countries is positively associated with their innovation performance.

In the context of external knowledge acquisition, strategic orientation is central to this learning process because firms may exhibit different learning behaviours in response to different motives, and the innovation gains may also vary accordingly. Effective cross-border learning needs a clear knowledge-seeking orientation by which MNEs are guided to design appropriate incentive schemes. These schemes will maximize the innovation performance from a given set of resources at various stages of the knowledge exploration, including discovering, assimilating, and translating into local use. Strategic orientation is critical to international knowledge acquisition, since a strong knowledge seeking orientation may inspire CMNEs to be more willing and active in tapping into new technologies when operating in a developed host country (Dunning and Narula, 1996; Cui et al., 2013). Therefore, the extent of knowledge acquisition through ODI will be significantly higher for knowledge seeking firms than those arriving at the host market with other motives, for example, market or nature resources-oriented or efficiencyseeking ODI.

Prior studies (Dunning and Narula, 1996; Cantwell and Jane, 1999) developed a conceptual link between the strategic orientation and technology diffusion of ODI in which the relationship between diversity knowledge sourcing and knowledge spillovers was postulated. Empirical evidence has also shown that strategic-asset seeking has become the most important motive when CMNEs go abroad (Luo and Tung, 2007; Lu et al., 2011; Deng, 2009; Rui and Yip, 2008). While there is a wealth of literature on the impact of ODI on the host country, research on the impact of ODI on investing firms, especially the impact of strategic asset-seeking ODI on investing firms in the context of emerging market MNEs, is limited. Little has been discussed about the moderating role of strategic orientation and how it leverages the impact of ODI on innovation performance. Although undertaking ODI in developed countries offers CMNEs novel technological resources that result in innovation gains, the extent of such innovation gains may be conditioned on the strategic orientation of CMNEs (Driffield and Love, 2007). We therefore examine whether knowledge-seeking orientation reinforces the relationship between ODI and innovation performance. This leads to the following hypothesis:

Hypothesis 1b: The positive impact of ODI in developed countries on innovation performance will be stronger for CMNEs with knowledge-seeking orientation than for those with other investment motives. 


\subsection{The relationship between ODI and in-house innovation}

As an alternative innovation source, ODI in developed countries can be regarded as an 'innovation springboard' and plays a similar role as in-house R\&D that fosters CMNEs' innovation. Specifically, ODI allows CMNEs to access external complementary innovation assets that enable them to break through the innovation bottleneck and result in positive returns from innovation $(\mathrm{Fu}, 2012)$. However, neither in-house R\&D nor ODI is costless. Especially, in order to undertake technology-oriented ODI, considerable investment and supporting resources are needed beforehand. CMNEs have to decide whether to develop technology internally or acquire it externally. Optimising resource allocation for both strategic options at the same time would become impossible due to the resource constraints and the organisational inertia (Fu, 2012). This is particularly true for CMNEs that need to make a trade-off between in-house R\&D and ODI. Yet at the current development stage of China, few firms would actually require the use of cutting-edge technologies. Even among those technology-oriented MNEs, their technology levels are not necessarily at the leading position of their industry. Most of them still try to catch up with rather than overtake the technological frontier. Therefore, the demands for $\mathrm{R} \& \mathrm{D}$ remain relatively low when compared to rivals from developed economies. The majority of CMNEs still rely on external knowledge acquisition to foster innovation because of limited in-house technological sourcing and R\&D capability. Although China's R\&D expenditure has increased rapidly especially in the past decade, internal resources that used to advance CMNEs' technological capability remained relatively scarce during our sample period. Hence, as an alternative knowledge creation channel, ODI in developed countries reduces the importance of the focal firm's R\&D in innovation performance.

In addition, ODI can indirectly contribute to firms' innovation by strengthening technological capability. CMNEs attempt to fill internal innovation gaps with opportunities coming from foreign territories, and seek alternative knowledge assets through ODI to compensate for weak internal technological capability (Chesbrough, 2003). Thus, engaging in ODI in developed countries may generate a positive innovation outcome that is similar to investment in (or more investment in) in-house $R \& D$ only. Previous studies denote such a relationship as the substitution between internal knowledge creation and external technology acquisition (Katrak, 1997; Blonigen and Taylor, 2000). In other words, ODI in developed countries may be treated as a replacement for in-house $\mathrm{R} \& \mathrm{D}$ as an alternative technological sourcing (Cantwell, 1989; Chesbrough, 2003). Furthermore, undertaking ODI in developed countries can encourage Chinese firms to undertake $R \& D$ activities in the host country due to effective legal protection 
for intellectual property rights. Such an environment may provide stronger incentives for Chinese overseas branches to engage in innovation rather than conducting $R \& D$ in the home country.

It is noted that domestic R\&D plays a dual role of being both innovation input and firms' absorptive capacity (Cassiman and Veugelers, 2006; Hou and Mohnen, 2013). Absorptive capacity represents internal learning and is viewed as a necessary complement to external knowledge sourcing especially for technology-intensive industries (Chesbrough and Crowther, 2006; Dahlander and Gann, 2010). However, this argument overlooks resource constraints encountered by EMNEs in developing absorptive capacity. Greater expenditures in in-house $R \& D$ would inhibit a firm from allocating resources to alternative external innovation activities due to the hard budget constraints (Chesbrough, 2003; Howells et al., 2004; Fu, 2012). This is particularly true for privately owned Chinese MNEs and those from other emerging countries, where market mechanisms are at play, and state-owned enterprises play a limited role in their economy. This argument is consistent with the fact that investment in R\&D is relatively low by Chinese firms, thus limiting the role of in-house $R \& D$ serving as absorptive capacity (Chesborough, 2003; Veugelers, 1997; Veugelers and Cassiman, 1999). As a result, there may be a substitution effect with ODI replacing absorptive capacity or domestic R\&D. Thus, we propose that

Hypothesis 2a: ODI in developed countries reduces the importance of CMNEs' in-house R\&D and hence the impact of in-house $R \& D$ on innovation performance is likely to be weakened.

Comparing to low-tech sectors, the advancement of high-tech industries in developed countries offers intensive knowledge contents in terms of both width and depth to Chinese firms. However, the technology gap between China and developed countries should not be ignored while assessing the learning effect of CMNEs in high-tech sectors (Kokko, 1992). Despite the gap between Chinese follower and western technological frontier has narrowed in recent years, there is still an evident distance for Chinese high-tech firms to catch-up and achieve leapfrogging. When the technology gap is too wide, knowledge may be difficult for the former to unwrap and translate into local use, as this transformation requires a significant amount of investment in advance (Greenaway and Milner, 1990). Although it remained inadequate to support ground-breaking inventions, the accumulated capability or narrowed gap has allowed Chinese manufacturers to imitate their western frontier, which has also given rise to the complaints about Chinese counterfeiting during this learning process. In such a context, 
acquiring technology externally (e.g. ODI) emerges as a cost-effective and substitute channel to in-house $R \& D$, given that the dynamic, high degrees of uncertainties, and risky features of high-tech sectors make in-house knowledge creation an even more costly process. In addition, the frequent occurrence of technology replacement in the high-tech industry needs persistent efforts and inputs. With the presence of hard budget constraints (Chesbrough, 2003; Fu, 2012), Chinese firms may allocate fewer available resources to alternative innovation activities. Thus, the existing technological gap between Chinese MNEs and technological leaders may make inhouse R\&D investment less effective comparing to external knowledge sourcing (Dahlander and Gann, 2010; Chesbrough and Crowther, 2006).

With less intensive technological contents and smaller technology gap, knowledge learning in low-tech sectors is less costly compared to high-tech sectors where great technological sophistication, heightened competitive intensity and a high level of uncertainty are present (Amadbile, 1997; Fu, 2011). The relatively small technology gap in low-tech sectors would allow CMNE followers to neutralize the competitive advantages of technological leaders. Catching-up would be easier through external technological acquisition via ODI and fewer resources would be consumed compared with high-tech sectors. Hence, we propose that the substitution effect between in-house R\&D and external technology sourcing through ODI will be stronger in high-tech industries than that in low-tech sectors. This leads to the following hypothesis:

Hypothesis 2b: The substitution effect between ODI in developed countries and the focal firms' in-house $R \& D$ will be stronger for firms operating in high-tech industries than those in lowtech industries.

\subsection{ODI, international experience and innovation performance}

Cross-border knowledge acquisition through ODI is not automatic (Kafouros et al., 2012), but depends on learning capability (Dunning, 1980; Dosi, 1988; Pavitt, 2005). Muehlfeld et al. (2012) stress that the ability to learn through ODI affects the extent of knowledge flows. Engaging in other international activities pre-ODI, such as exporting, helps firms enhance their learning capability (Dunning, 1998; Luo and Wang, 2012). In this regard, prior international experience is needed to understand the tacit components of foreign technology (Lall, 1989; Mowery and Oxley, 1995). Prior international experience also allows firms to improve their 
understanding and competence in foreign markets, build relational assets and develop foreign market entry capability that all help mitigate information asymmetry and uncertainty associated with ODI.

In addition, learning by exporting has been widely acknowledged as a mechanism to develop capabilities for partner formation, faster progress (Reuber and Fischer, 1997; Teece et al., 1997; Zollo and Winter, 2002) and cross cultural adjustment (Takeuchi et al., 2005). Therefore, international experience through exporting will help firms successfully enter an international market and compete with foreign rivals (Wagner, 2007; Ito and Wakasugi, 2007), which implies a complementary effect between prior international experience and the impact of ODI on innovation performance. Meanwhile, by engaging in the international production chain through exporting, CMNEs are able to accumulate technological capability. In addition, such an internationalisation process also helps CMNEs to strengthen the breadth and depth of international networks. The greater the CMNEs are embedded in global networks the more likely they are to better identify compatible technology sources, and assimilate and integrate external knowledge.

Furthermore, the moderating effect of prior experience on the relationship between ODI and innovation performance may depend on the industry context. It is likely that firms from a hightech industry would have different ways to absorb foreign knowledge because of a high level of implicit know-how involved (Senker, 1993; Makino and Lau, 1998). International experience is particularly important to firms in high-tech industries where tacit components account for a large part of core technology, and radical innovation often occurs. Thus, past international experience in this context would facilitate more effective foreign knowledge acquisition than in the traditional industries. Therefore, we propose:

Hypothesis 3a: The positive impact on innovation performance of ODI in developed countries will be stronger for the focal firms with previous international experience.

Hypothesis 3b: The complementarity between international experience and ODI in developed countries will be stronger for firms operating in high-tech industries.

\section{Methodology}

\subsection{Model}


The empirical model considers innovation as a function of ODI and interactions between ODI and R\&D as well as ODI in different host countries and different industries. The following equation summarizes our estimations.

$$
\begin{aligned}
& \text { Inno }_{i t}^{*}=\alpha+\beta_{o} O F D I_{i t}+\beta_{r} R \& D_{i t}+\beta_{o r} O F D I_{i t} * R \& D_{i t}+\beta_{e} E X P_{i t}+\beta_{t} T E C_{i t}+\beta_{s} S O E_{i t} \\
& +\beta_{a} \text { age }_{i t}+\beta_{l} \text { Scale }_{i t}+\beta_{h} \text { Hitech }_{i t}+\beta_{i d} \text { Indum }_{i t}+\varepsilon_{i t} \\
& \text { Inno }_{i t}=\left\{\begin{array}{cl}
\text { Inno }_{i t}^{*} & \text { if } \quad \text { Inno }_{i t}^{*}>0 \\
0 & \text { otherwise }
\end{array}\right. \\
& { }_{i t}={ }_{i}+{ }_{t}+u_{i t}
\end{aligned}
$$

Owing to its censored property, innovation performance, measured as the ratio of new product sales, of firm $i$ in year $t$ is observed only if strictly positive. Firms' ODI activities (OFDI) are included in equation (1) as explanatory variables. $R \& D$ performs two roles: a direct innovation source and a moderator that affects the impact of ODI on firms' new innovation performance. A set of control variables that captures firm characteristics and industry specifics, including exporting intensity (EXP), investment motives (TEC), ownership structure (SOE), scale and industrial properties (HITECH and Indum), enters equation (1) and jointly determines the innovation performance. and are the corresponding coefficients to be estimated.

The error term can be decomposed into three orthogonal components. $\omega_{i}$ indicates the timeinvariant individual effects which are unobserved by the econometrician but known to the firms (such as managerial ability or organisational ability). $\lambda_{t}$ captures the time effects which represent all the unobservable characteristics of time period $t$, constant for all the crosssectional units in the sample. In addition, $u_{i t}$ is an idiosyncratic error that varies over time and individual firms. It is assumed that $u_{i t}$ are uncorrelated with past values of the explanatory variables. Having considered the fact that it allows us to keep time-invariant variables, the Random effects model is adopted in the empirical estimations (Greene, 2003).

Using locality to explain the heterogeneous performance of innovation, the sample firms' ODI activities are distinguished by destinations: developed countries and developing countries. ${ }^{2}$

\footnotetext{
2 The classification of developed and developing countries here is based on the R\&D spending in GDP ratio of the host country. One will be considered as a developed country if the R\&D by GDP is above 1 per cent, otherwise it will be considered as a developing country. The reason for using R\&D in GDP ratio here is to try to focus more on the knowledge spillover potentials of a destination country rather than merely relying on the income level of a country. Investing in technology-intensive economies accommodates relatively larger-sized
} 
Depd and Depi denote whether firms' ODIs are conducted in developed or developing economies. Meanwhile, the impact of ODI on firms' innovation performance may be moderated by factors such as firms' overseas investment motivation (TECHit), prior international experiences (EXPit), in-house $R \& D$ intensity $(R \& D i t)$ and industrial specificities. The moderating effects will be captured by interaction terms and a full model is expanded to

$$
\begin{aligned}
& \operatorname{Inno}_{i t}^{*}\left(I \in\left(R \& D_{i t}, \operatorname{EXP}_{i t}, T E C H_{i t}\right)\right)=\alpha+I^{*}\left(\beta_{d d} D_{\text {Depd_OFDI }}+\beta_{d i} \text { Depi_OFDI }{ }_{i t}\right) \\
& +\beta_{r} R \& D_{i t}+\beta_{e} E X P_{i t}+\beta_{t} \text { TECH }_{i t}+\beta_{s} S O E_{i t}+\beta_{a} a g e_{i t}+\beta_{l} \text { Scale }_{i t} \\
& +\beta_{h} \text { Hitech }_{i t}+\omega_{i}+\lambda_{t}+u_{i t}
\end{aligned}
$$

Removing the time-invariants (such as SOE, Hitech and $\omega$ ) by a fixed effect approach will not affect the consistency of other coefficients in (3) if the specification is a linear relationship and there are no serious correlations between explanatory variables. Yet with the censored observation on the dependent variable, a fixed effect model is not able to devise a consistent estimator (Maddala, 1987) and therefore this current study chooses to adopt a Random Tobit methodology.

\subsection{Data}

The firm-level data used in the empirical analysis come from a purpose-designed survey on the determinants and impacts of Chinese firms' outward direct investment, which was carried out by a collaborative research team of British and Chinese universities in Guangdong province in $2010{ }^{3}$ Guangdong Province is located on the shore of the South China Sea, adjacent to the Hong Kong Special Administrative Region (SAR). It shares the largest proportion of China's total economic output. The exports of Guangdong accounted for more than $25 \%$ of China's exports in $2010^{4}$. As the province that first opened up to international trade and investment, Guangdong also witnessed increasing cross-border investment activities of its firms. The total volume of the ODI from Guangdong in 2010 accounted for $19.3 \%$ of the stock of China's ODI. Its non-financial overseas investment in 2014 reached 49.48 USD billion, making $6.64 \%$ of the

knowledge pools for Chinese MNEs to learn and assimilate. Although the income level is in the upper rank, the potential of technology learning would be limited if a country's growth were based on a resource-driven model, such as countries in the Middle East.

${ }^{3}$ The implementation of the survey received tremendous support from Guangdong Commission of Foreign Trade \& Economic Cooperation as well as the Guangdong Research Institute for International Strategies.

${ }^{4}$ Data source: China Statistical Yearbook 2010, National Bureau of Statistics of China. http://www.stats.gov.cn 
stock of China's total ODI. ${ }^{5}$ Hence, it represents an ideal research setting to examine the impact of ODI on innovation performance.

Given the fact that there was only a small proportion of Chinese firms that had invested abroad back at the time when the survey was conducted, and that even in Guangdong these firms were highly concentrated in the Pearl River Delta, the survey sampling focused on the firms in this region. Therefore, the sampling framework of the survey was drawn from firms that had overseas direct investment or were regarded as having the potential to go global. The latter group of firms has been selected mainly based on their financial and growth performance, outward orientation, and their interest in OFDI as indicated to the local committees of foreign trade. Questionnaires were posted to 2,000 firms that met these criteria in all industries around the Pearl River Delta region. In total, 341 valid responses were received, implying a response rate of $17.1 \%$. The researchers also interviewed senior managers and business owners of 21 firms to cross check the questionnaire responses and to gain further qualitative insights concerning the motivation and impact of overseas investment.

Among these 341 responses, 299 were private-owned and 26 were public-owned (we were unable to identify the ownership of the remaining 16 firms). 328 firms provided information on their registered industry/trade, including 267 manufacturing firms, 23 enterprises involved in wholesale and retail, 9 IT service companies and 29 firms in other industries. 80 of these 328 firms reported that they had had overseas investment experience, accounting for 23 per cent of total firms in the sample. After eliminating missing values ${ }^{6}$, we are left with a three years balanced panel, comprising 567 observations from 25 industries for the period of 2007 to 2009 .

The respondents were asked to report information of ODI, including strategic orientation and investment destinations. Having compiled a list of countries, we differentiate these destinations into developed or developing countries based on R\&D/GDP ratio $^{7}$. The mean values of ODI_Depd and ODI_Depi, 0.085 and 0.053 respectively shown in Table 1, suggest that

\footnotetext{
${ }^{5}$ Data source: Guangdong Statistical Yearbook 2015, Guangdong Bureau of Statistics. http://www.gdstats.gov.cn/tjsj/gdtjnj/

${ }^{6}$ There are in total 139 observations that are eliminated from the sample due to missing values in at least one of the following categories: 1) 106 firms did not report if they had engaged in ODI activities; 2) 109 did not provide information with regard to innovation status; 3 ) the turnover of 81 firms during the period under survey is missing.

${ }^{7}$ Given that some developed economies are based on resources-based growth, it is more rational to divide ODI hosting countries by their R\&D/GDP ratio, which is particularly relevant for technology exploration ODI.
} 
CMNEs tend to choose developed countries as their investment destinations. The descriptive statistics also show that acquiring foreign knowledge is one of the primary motives of CMNEs.

The dependent variable, Innoit, in equations (1) and (3) is innovation performance, measured by the proportion of new product sales in the total sales. Innoit is strictly positive and conditional on the innovativeness of firms (Inno Dum), indicating that only innovators yield positive new product sales. Inno_Dum takes the value 1 if a firm claimed to be an innovator, regardless of product or process innovation. Compared to other measures of innovation performance, for example, patents, the introduction of new products and its market value emphasize in particular the direct link between innovation effort and commercially useful output (Chudnovsky et al., 2006).

A series of variables are included in equation (3) to determine the sales of new products. One of the most prominent ones is the extent to which a firm invests in innovation (Crépon et al., 1998; Mairesse and Mohnen, 2002; Griffith et al., 2006), measured by the natural logarithm of R\&D expenditures in China. ${ }^{8}$ The greater a firm's efforts in R\&D investment, the better its innovation performance measured by new product sales. One of the core concerns in the current study is to investigate if ODI affects a focal firm's innovation performance. Another explanatory variable included is the destination of ODI with respect to developed (Depd_ODI) or developing (Depi_ODI) countries. They are a set of dummy variables taking the value 1 if a firm has conducted corresponding ODI, zero otherwise. Firms are expected to learn and reinforce their innovation performance while conducting investment activities abroad, especially in developed countries.

Three variables enter equation (3) to interact with ODI, expecting to yield moderating effects. Besides directly contributing to the innovation output, $R \& D$ also affects the innovation effect of ODI indirectly as a moderator. EXP is the ratio of exports to turnover, capturing the prior international experiences. TECH takes the value 1 if a firm's ODI motivation is knowledgeexploration, zero otherwise.

In addition, a category of firm and industry specifics is captured by a set of control variables. The number of total employees in natural logarithm serves as an indicator of the scale. With a larger scale of production, firms possess relatively adequate resources and are therefore more likely to invest in innovation (Katrak, 1997). Ownership may act as a crucial factor to

\footnotetext{
${ }^{8}$ The R\&D expenditure of a firm does not include the R\&D spending occurred in its overseas R\&D centre.
} 
innovation in the case of China, as it affects the motivation to innovate and the continuity of business strategy. State-owned enterprises (SOEs) usually receive large investment subsidies and tax incentives from the government. Yet the effect of SOEs on innovation output is ambiguous, given that they are also characterised as ones that inherited many inefficiencies from the formal central-planned economy and are reluctant to undertake changes (Javorcik, 2004; Hou and Mohnen, 2013; Zhang, 2014). We also account for the scale (Scale) of firms, measured by the number of employees in natural logarithm. Large firms possess relatively more resources which can benefit innovation, while small firms are likely to perform more actively in terms of innovation activities. The scale effect is therefore ambiguous. Innovation activities tend to be relatively more intensive in more technologically advanced industries, such as pharmaceuticals, electrical equipment, and electronics. The control variable Hi-tech categorises firms which are from a High-tech industry ${ }^{9}$. Sector dummies (Sector_dum) are also included to control for industry specifics.

Table 1. Summary of variables

\begin{tabular}{|c|c|c|c|}
\hline Variable & Definition & Mean & Std. Dev. \\
\hline \multicolumn{4}{|c|}{ Dependent variable } \\
\hline Inno & New product sales/total sales & 0.230 & 0.325 \\
\hline Inno_Dum & Value 1 if a firm is an innovator & 0.836 & 0.371 \\
\hline \multicolumn{4}{|c|}{ Explanatory variable } \\
\hline ODI & Value 1 if a firm has ODI investment & 0.143 & 0.350 \\
\hline Depd_ODI & $\begin{array}{l}\text { Value } 1 \text { if a firm's ODI operates in } \\
\text { developed countries, } 0 \text { otherwise. }\end{array}$ & 0.085 & 0.278 \\
\hline Depi_ODI & $\begin{array}{l}\text { Value } 1 \text { if a firm's ODI operates in } \\
\text { developing countries, } 0 \text { otherwise. }\end{array}$ & 0.053 & 0.244 \\
\hline \multicolumn{4}{|l|}{ Moderators } \\
\hline $\mathrm{R} \& \mathrm{D}$ & Annual $R \& D$ expenditure in China, in $\log$ & 3.280 & 3.284 \\
\hline EXP & Ratio of export to total sales & 0.077 & 0.189 \\
\hline TECH & $\begin{array}{l}\text { Value } 1 \text { if a firm's ODI motivation is } \\
\text { knowledge-exploration, } 0 \text { otherwise }\end{array}$ & 0.108 & 0.310 \\
\hline \multicolumn{4}{|l|}{ Control variables } \\
\hline SOEs & $\begin{array}{l}\text { Value } 1 \text { if a firm is state-owned, } 0 \\
\text { otherwise. }\end{array}$ & 0.069 & 0.253 \\
\hline Scale & Number of total employees, in log & 5.561 & 2.010 \\
\hline Hitech & $\begin{array}{l}\text { Value } 1 \text { if a firm is in high-tech or } \\
\text { intermediate-tech industries }\end{array}$ & 0.265 & 0.441 \\
\hline Sector_Dum & Sector dummies & \multicolumn{2}{|c|}{ Included } \\
\hline No. observations & Total number of observation, 3 years & \multicolumn{2}{|c|}{567 (pooled) } \\
\hline
\end{tabular}

\footnotetext{
${ }^{9}$ The classification of High-tech industry is based on OCED ISIC Rev. 3 Technology Intensity Definition
} 
Table 1 gives the summary of variables in the empirical estimation. Given the fact that the sample was drawn from potential ODI firms with relatively better financial and growth performance, it may possibly suffer from sample selection bias because it may only include innovation active firms. Table 1 shows that more than 80 percent of the sample firms recognise themselves as innovators, regardless of being a product, process, or managerial innovator. Yet, such bias is inevitable in studies concerning the relationship between ODI and innovation since ODI firms in general outperform others and are more active in learning than others in order to compete with foreign rivals. In addition, the main concern (dependent variable) of equation (3) is the intensity of innovation, measured by the ratio of innovation sales instead of the likelihood of innovation. It is unlikely to bring substantial noise to the empirical results.

The correlation matrix of variables is presented in Table 2. It is worth noting that Chinese ODI, regardless of being to developing or developed countries, is positively correlated with $R \& D$, firms' prior experience and knowledge-orientation. The ratio of new product sales is positively correlated with ODI undertaken in developed economies. On the contrary, it becomes a negative correlation when ODI is undertaken in developing countries.

Table 2. Correlations between ODI and firm characteristics

\begin{tabular}{lrrrrrrrrrr}
\hline & $\begin{array}{l}\text { Innova } \\
\text { tion }\end{array}$ & $\begin{array}{l}\text { ODI } \\
\text { DUM }\end{array}$ & $\begin{array}{l}\text { Depd_ } \\
\text { ODI }\end{array}$ & $\begin{array}{l}\text { Depi_ } \\
\text { ODI }\end{array}$ & R\&D & EXP & $\begin{array}{l}\text { TEC } \\
\text { H }\end{array}$ & SOE & Scale & $\begin{array}{l}\text { Hitec } \\
\text { h }\end{array}$ \\
\hline Innovation & 1 & & & & & & & & & \\
ODI Dum & 0.08 & 1 & & & & & & & & \\
ODI_Depd & 0.19 & 0.74 & 1 & & & & & & & \\
ODI_Depi & -0.10 & 0.58 & -0.07 & 1 & & & & & & \\
R\&D & 0.60 & 0.16 & 0.24 & -0.05 & 1 & & & & & \\
EXP & -0.12 & 0.02 & -0.06 & 0.02 & -0.18 & 1 & & & & \\
TECH & 0.05 & 0.08 & 0.09 & 0.03 & 0.00 & -0.08 & 1 & & & \\
SOE & 0.00 & 0.19 & 0.14 & 0.12 & 0.15 & -0.09 & 0.05 & 1 & & \\
Scale & 0.13 & 0.17 & 0.12 & 0.12 & 0.35 & -0.03 & 0.01 & 0.26 & 1 & \\
Hitech & 0.17 & 0.13 & 0.12 & 0.07 & 0.19 & -0.06 & 0.09 & 0.11 & 0.00 & 1 \\
\hline
\end{tabular}

\section{Empirical results}

To test the extent to which ODI affects the innovation performance of Chinese firms in the presence of several moderators, the Random Tobit (RM) is adopted to estimate equation (3). Different specifications are presented based upon different moderators: R\&D (Model 1), exporting experiences (Model 2) and technology-seeking motivation (Model 3). The full model which includes all three moderators is presented in Model 4. 
Table 3 reports the estimated coefficients. The results are presented based on the full sample, as well as dividing it into High-tech and Low-tech firms. Standard errors are included in parentheses. The significance of correlation coefficients 'Rho' at 1 per cent throughout all subsamples suggests that the bias caused by the right censoring of the dependent variable, exists, and the Tobit model generates more consistent results compared to the Ordinary Least Square approach. The lower panel of Tables 3 presents the conditional marginal effects of corresponding variables. We start by discussing the results of explanatory and control variables, and then move to the moderators.

$\mathrm{R} \& \mathrm{D}$ expenditure, as one of the major sources of innovation, is shown to directly contribute to new product sales. Such effects are consistent across all specifications as shown from Model 1 to Model 4 in Table 3, suggesting that 1 percentage increases in $R \& D$ expenditure yields approximately 3.5 - 5.0 percentage-points more in new product sales. Similarly, consistent estimators are found for SOEs in the 'Full Sample'. It suggests that Chinese firms with major state ownership tend to be less innovative compared to firms having other ownership structures, about 11-17 percentage-points lower in new product sales if a firms is state owned. Although Chinese SOEs enjoy the priority of receiving financial and policy support from the Chinese government, most of them, to some extent, still suffer from inefficiencies inherited from the formal planned economy system.

We found high-tech CMNEs with knowledge exploration orientation are likely to increase the ratio of their new product sales by 15-19 percentage-points. Such effect is insignificant within firms in the low-tech industries. A possible explanation for this is that low-tech CMNEs are not motivated by technology-oriented strategies while undertaking ODI. They compete in the international market with their price advantage. Nevertheless, the interpretation of the variable TECH also needs to consider the potential interactive effects with ODI, which are discussed in the marginal effect section. Although prior exporting experiences do not seem to directly associate with firms' innovation performance, reflected by the statistically insignificant coefficients of EXP, different signs of the estimates appeared across different industry contexts, positive for High-tech and negative for Low-tech industries. EXP becomes significant while interacting with ODI variables, suggesting the moderating role of prior international experiences. Meanwhile, the coefficient measuring scale is negative though insignificant. This result indicates that the scale effect is rather mixed, meaning that large firms with resource are not active in innovation while small firms which are active in innovation in general lack resources. 
The moderating effects of R\&D, EXP and TECH are confirmed, reflected by the significant interaction terms especially in the full sample and subsample of High-tech firms. Specifically, the level of R\&D investment and the presence of ODI in developed countries jointly affect the innovation performance of CMNEs. The negative and significant sign of Depd_ODI*R\&D suggests that ODI in developed countries can serve as a substitute innovation source and reduce the importance of CMNEs' in-house R\&D. Such substitutive effects are more pronounced in high-tech sectors than low-tech ones. On the other hand, the results show that both prior intentional experiences $(E X P)$ and strategic orientation $(T E C H)$ positively moderate the innovation-enhancing effect of ODI undertaken in developed countries. Such an effect is particularly relevant for CMNEs in high-tech sectors. For these firms that undertake ODI in developed countries, past international experience and strong knowledge -seeking motive are likely to improve their innovation performance via ODI. Thus, the results are consistent with previous studies (Chen and Tang, 2016) and confirm that there is in general a positive and statistically significant association between the intensity of innovation and ODI undertaken in developed countries (Depd_ODI), suggesting that investment destination matters in the relationship between ODI activities and innovation performance. Complementing prior research, we move beyond preliminary interpretation by taking into account the interactive terms and graphically displaying the marginal effects of the interactive terms. 
Table 3 Random Tobit estimation results

\begin{tabular}{|c|c|c|c|c|c|c|c|c|c|c|c|c|}
\hline \multirow[b]{2}{*}{ VARIABLES } & \multicolumn{4}{|c|}{ Full Sample } & \multicolumn{4}{|c|}{ High-tech Firms } & \multicolumn{4}{|c|}{ Low -tech Firms } \\
\hline & Model 1 & Model 2 & Model 3 & Model 4 & Model 1 & Model 2 & Model 3 & Model 4 & Model 1 & Model 2 & Model 3 & Model 4 \\
\hline$R \& D$ & $0.116^{* * *}$ & $0.100^{* * * *}$ & $0.098 * * *$ & $0.115^{* * * *}$ & $0.133 * * *$ & $0.114 * * *$ & $0.112 * * *$ & $0.132 * * *$ & $0.111 * * *$ & $0.095 * * *$ & $0.094 * * *$ & $0.110 * * *$ \\
\hline EXP & 0.018 & 0.004 & 0.015 & 0.017 & 0.092 & 0.095 & 0.129 & 0.087 & -0.000 & -0.013 & -0.009 & -0.001 \\
\hline & $(0.106)$ & $(0.109)$ & $(0.108)$ & $(0.106)$ & $(0.227)$ & $(0.260)$ & $(0.235)$ & $(0.224)$ & $(0.126)$ & $(0.129)$ & $(0.128)$ & $(0.126)$ \\
\hline TECH & $\begin{array}{c}0.045 \\
(0.060)\end{array}$ & $\begin{array}{c}0.064 \\
(0.061)\end{array}$ & $\begin{array}{c}0.041 \\
(0.062)\end{array}$ & $\begin{array}{c}0.028 \\
(0.061)\end{array}$ & $\begin{array}{l}0.181 * \\
(0.096)\end{array}$ & $\begin{array}{l}0.191 * * \\
(0.095)\end{array}$ & $\begin{array}{l}0.168^{*} \\
(0.097)\end{array}$ & $\begin{array}{c}0.145 \\
(0.097)\end{array}$ & $\begin{array}{l}-0.019 \\
(0.079)\end{array}$ & $\begin{array}{c}0.002 \\
(0.080)\end{array}$ & $\begin{array}{l}-0.010 \\
(0.082)\end{array}$ & $\begin{array}{l}-0.015 \\
(0.081)\end{array}$ \\
\hline SOEs & $-0.301^{* *}$ & $-0.318^{* *}$ & $-0.301 * *$ & $-0.286^{*}$ & -0.189 & -0.261 & -0.250 & -0.155 & -0.475 & -0.407 & -0.405 & -0.488 \\
\hline Scale & $\begin{array}{l}(0.146) \\
-0.011\end{array}$ & $\begin{array}{l}(0.148) \\
-0.002\end{array}$ & $\begin{array}{c}(0.144) \\
-0.001\end{array}$ & $\begin{array}{l}(0.147) \\
-0.010\end{array}$ & $\begin{array}{l}(0.170) \\
-0.020\end{array}$ & $\begin{array}{l}(0.165) \\
-0.008\end{array}$ & $\begin{array}{l}(0.163) \\
-0.008\end{array}$ & $\begin{array}{l}(0.167) \\
-0.019\end{array}$ & $\begin{array}{l}(0.302) \\
-0.009\end{array}$ & $\begin{array}{l}(0.339) \\
-0.001\end{array}$ & $\begin{array}{c}(0.330) \\
0.001\end{array}$ & $\begin{array}{l}(0.303) \\
-0.007\end{array}$ \\
\hline & $(0.010)$ & $(0.009)$ & $(0.009)$ & $(0.010)$ & $(0.013)$ & $(0.012)$ & $(0.012)$ & $(0.013)$ & $(0.015)$ & $(0.015)$ & $(0.015)$ & $(0.015)$ \\
\hline Hi-tech & $\begin{array}{c}0.050 \\
(0.064)\end{array}$ & $\begin{array}{c}0.056 \\
(0.066)\end{array}$ & $\begin{array}{c}0.066 \\
(0.066)\end{array}$ & $\begin{array}{c}0.053 \\
(0.064)\end{array}$ & & & & & & & & \\
\hline Depd_ODI & $\begin{array}{c}0.724 * * * \\
(0.129)\end{array}$ & $\begin{array}{c}0.057 \\
(0.076)\end{array}$ & $\begin{array}{l}-0.034 \\
(0.094)\end{array}$ & $\begin{array}{c}0.582 * * * \\
(0.176)\end{array}$ & $\begin{array}{c}0.837 * * * \\
(0.244)\end{array}$ & $\begin{array}{c}-0.042 \\
(0.088)\end{array}$ & $\begin{array}{l}-0.147 \\
(0.122)\end{array}$ & $\begin{array}{c}0.794 * * \\
(0.324)\end{array}$ & $\begin{array}{c}0.705^{* * *} \\
(0.161)\end{array}$ & $\begin{array}{c}0.203 \\
(0.133)\end{array}$ & $\begin{array}{c}0.112 \\
(0.145)\end{array}$ & $\begin{array}{c}0.649 * * * \\
(0.235)\end{array}$ \\
\hline Depi_ODI & $\begin{array}{c}0.143 \\
(0.162)\end{array}$ & $\begin{array}{l}-0.007 \\
(0.092)\end{array}$ & $\begin{array}{c}0.056 \\
(0.108)\end{array}$ & $\begin{array}{c}0.115 \\
(0.190)\end{array}$ & $\begin{array}{c}0.267 \\
(0.218)\end{array}$ & $\begin{array}{l}-0.024 \\
(0.114)\end{array}$ & $\begin{array}{c}0.110 \\
(0.161)\end{array}$ & $\begin{array}{c}0.233 \\
(0.282)\end{array}$ & $\begin{array}{c}0.037 \\
(0.262)\end{array}$ & $\begin{array}{c}0.065 \\
(0.273)\end{array}$ & $\begin{array}{c}0.017 \\
(0.152)\end{array}$ & $\begin{array}{c}0.198 \\
(0.311)\end{array}$ \\
\hline Depd_ODI*R\&D & $\begin{array}{c}-0.091 * * * \\
(0.018)\end{array}$ & & & $\begin{array}{c}-0.086^{* * *} \\
(0.019)\end{array}$ & $\begin{array}{c}-0.115 * * * \\
(0.032)\end{array}$ & & & $\begin{array}{c}-0.124 * * * \\
(0.038)\end{array}$ & $\begin{array}{c}-0.080 * * * \\
(0.023)\end{array}$ & & & $\begin{array}{c}-0.078 * * * \\
(0.024)\end{array}$ \\
\hline Depi_ODI*R\&D & $\begin{array}{l}-0.018 \\
(0.026)\end{array}$ & & & $\begin{array}{l}-0.016 \\
(0.026)\end{array}$ & $\begin{array}{l}-0.035 \\
(0.032)\end{array}$ & & & $\begin{array}{l}-0.037 \\
(0.034)\end{array}$ & $\begin{array}{l}-0.008 \\
(0.046)\end{array}$ & & & $\begin{array}{l}-0.029 \\
(0.163)\end{array}$ \\
\hline Depd_ODI*EXP & & $\begin{array}{l}1.952^{*} \\
(1.092)\end{array}$ & & $\begin{array}{l}-0.024 \\
(1.134)\end{array}$ & & $\begin{array}{l}2.747 * \\
(1.657)\end{array}$ & & $\begin{array}{l}-1.200 \\
(1.962)\end{array}$ & & $\begin{array}{c}0.606 \\
(1.706)\end{array}$ & & $\begin{array}{l}-0.283 \\
(1.702)\end{array}$ \\
\hline Depi_ODI*EXP & & $\begin{array}{l}1.693 \\
(2.422)\end{array}$ & & $\begin{array}{c}0.990 \\
(2.504)\end{array}$ & & $\begin{array}{l}1.951 \\
(2.358)\end{array}$ & & $\begin{array}{c}0.815 \\
(2.874)\end{array}$ & & $\begin{array}{c}-97.633 \\
(418.424)\end{array}$ & & $\begin{array}{c}-25.254 \\
(1,438.783)^{10}\end{array}$ \\
\hline Depd_ODI*TEC & & & $\begin{array}{c}0.293 * * \\
(0.124)\end{array}$ & $\begin{array}{c}0.189 \\
(0.124)\end{array}$ & & & $\begin{array}{l}0.292 * \\
(0.170)\end{array}$ & $\begin{array}{c}0.253 \\
(0.164)\end{array}$ & & & $\begin{array}{c}0.200 \\
(0.184)\end{array}$ & $\begin{array}{c}0.096 \\
(0.186)\end{array}$ \\
\hline Depi_ODI*TEC & & & $\begin{array}{l}-0.052 \\
(0.168)\end{array}$ & $\begin{array}{l}-0.004 \\
(0.174)\end{array}$ & & & $\begin{array}{l}-0.088 \\
(0.202)\end{array}$ & $\begin{array}{c}0.068 \\
(0.260)\end{array}$ & & & $\begin{array}{c}-1.756 \\
(136.408)\end{array}$ & $\begin{array}{c}-1.494 \\
(70.939)\end{array}$ \\
\hline Constant & $\begin{array}{c}-0.663 * * \\
(0.264)\end{array}$ & $\begin{array}{c}-0.657 * * \\
(0.256)\end{array}$ & $\begin{array}{c}-0.641 * * * \\
(0.236)\end{array}$ & $\begin{array}{c}-0.655^{* *} \\
(0.265)\end{array}$ & $\begin{array}{c}-0.418 * * * \\
(0.093)\end{array}$ & $\begin{array}{c}-0.395 * * * \\
(0.089)\end{array}$ & $\begin{array}{c}-0.373 * * * \\
(0.089)\end{array}$ & $\begin{array}{c}-0.395 * * * \\
(0.091)\end{array}$ & $\begin{array}{c}-0.620^{* * *} \\
(0.242)\end{array}$ & $\begin{array}{c}-0.631 * * * \\
(0.233)\end{array}$ & $\begin{array}{c}-0.605 * * * \\
(0.223)\end{array}$ & $\begin{array}{c}-0.607 * * * \\
(0.235)\end{array}$ \\
\hline Rho & $\begin{array}{c}0.368 * * * \\
(0.027)\end{array}$ & $\begin{array}{c}0.375 * * * \\
(0.029)\end{array}$ & $\begin{array}{c}0.377 * * * \\
(0.029)\end{array}$ & $\begin{array}{c}0.366 * * * \\
(0.027)\end{array}$ & $\begin{array}{c}0.348 * * * \\
(0.040)\end{array}$ & $\begin{array}{c}0.363 * * * \\
(0.042)\end{array}$ & $\begin{array}{c}0.359 * * * \\
(0.042)\end{array}$ & $\begin{array}{c}0.339 * * * \\
(0.039)\end{array}$ & $\begin{array}{c}0.369 * * * \\
(0.036)\end{array}$ & $\begin{array}{c}0.372 * * * \\
(0.038)\end{array}$ & $\begin{array}{c}0.379 * * * \\
(0.039)\end{array}$ & $\begin{array}{c}0.373 * * * \\
(0.037)\end{array}$ \\
\hline Observations & 567 & 567 & 567 & 567 & 198 & 198 & 198 & 198 & 369 & 369 & 369 & 369 \\
\hline Number of firms & 189 & 189 & 189 & 189 & 66 & 66 & 66 & 66 & 123 & 123 & 123 & 123 \\
\hline
\end{tabular}

Standard errors in parentheses, sector dummies are included: Manufacturing (516 observations), Service (24 ob.), Other (27 ob.)

$* * * \mathrm{p}<0.01, * * \mathrm{p}<0.05, * \mathrm{p}<0.1$

The standard errors for marginal effects are computed by using Delta method.

${ }^{10}$ The substantially high standard errors in sub-sample of Low-tech firms in Table 3 may raise potential collinearity due to the presence of many interactions. Nevertheless, the statistical inferences with respect to other variables in the equation remain efficient. 
Table 4 presents the conditional marginal effects of the main variables of interest on the ratio of new product sales. The computation of marginal effects is based on Model 4 in Table 3, with controlling for the interactive effects between ODI and moderators. ${ }^{11}$ The results are presented based on the full sample, and on high-tech and low-tech sub-samples. Overall, conducting investments in a foreign country stimulates the innovation performance of our sample firms. After taking into account the moderating effects, the positive innovation effect is again only confirmed among CMNEs conducting ODI in developed countries (Hypothesis 1a). The marginal effect of having ODI in developed countries is significant at the 1 per cent level and a unit increase in investing ODI in developed markets boosts new product sales by almost 13.2 percentage points holding other factors - the potential moderating effects of R\&D, export and motivations - equal. The composite effect, direct and moderating effects, of $R \& D$ ranges from 3.7-5.0 percentage points, meaning that every extra percentage unit of R\&D expenditure yields additional 3.7-5.0 percentage points to the ratio of new product sales. Given the technologyintensive nature, firms in high-tech sectors rely heavily on $R \& D$ as a major innovation source and this is reflected by the highest marginal effect among all the samples. The composite effect of TECH only appears among the high-tech group, significant at the 5 per cent level. The result suggests that firms with specific technology-seeking motivation tend to have on average 8.1 percentage points higher innovation sales compared to those with other motives.

The graphic plotting of the moderating effect of $R \& D$ is shown in Figure $1^{12}$ and further confirms our findings. A high level of R\&D investment strengthens the innovation effect of ODI undertaken in developed countries whereas such a moderating effect appears to be less effective to ODI conducted in developing countries. Moreover, Chinese firms in high-tech

\footnotetext{
11 The marginal effects of explanatory variables on the new product sales are calculated at the corresponding means, conditional on the uncensored sample, taking into account the moderating effects of R\&D, export and technology motivation. In horizontal row 3 - 5 of Table 4 we report the conditional marginal effects of R\&D, Depd_ODI and Depi_ODI. For example, when computing the marginal effects of R\&D, we take into account all the terms where R\&D appears, including R\&D, Depd_ODI*R\&D and Depi_ODI*R\&D. In the horizontal row below Full model, the conditional marginal effect of Depd_ODI takes into account four terms simultaneously, which are Depd_ODI, Depd_ODI*R\&D, Depd_ODI*Export and Depd_ODI*Tech. Standard Errors are computed using the Delta method.

${ }^{12}$ Graph 1 is drawn on the mean values of corresponding explanatory variables. As the major input of innovation, the R\&D investment explains the innovation sales level and, at the same time, moderates the innovation effects of ODI. ODI enters the knowledge creation process as another effective innovation source and explains the levels of innovation, especially ODI invested in developed economies. Since no complementary effect is observed for Depi_ODI and R\&D, the slope of Depi_ODI will only depend on the marginal returns of $R \& D$ alone. The complementarity explains the difference in intercepts and slopes of two lines.
} 
industries with a technology-exploration motive are likely to yield more new product sales, although such a significant effect does not hold for other groups (Hypothesis 1b).

Table 4. Conditional marginal effects with controlling for the interactive effects in Model 4, at the mean values

\begin{tabular}{l|cc|cc|cc}
\hline \multirow{2}{*}{} & \multicolumn{2}{|c|}{ Full } & \multicolumn{2}{c|}{ Hi-tech } & \multicolumn{2}{c}{ Low-tech } \\
\cline { 2 - 7 } & Coef. & Std. Err. & Coef. & Std. Err. & Coef. & Std. Err. \\
\hline \multirow{2}{*}{ R\&D } & & & & & & \\
Export & $0.037^{* * *}$ & 0.003 & $0.050^{* * *}$ & 0.007 & $0.029 * * *$ & 0.002 \\
Tech & 0.023 & 0.067 & -0.003 & 0.182 & -0.301 & 16.724 \\
Developed & 0.015 & 0.021 & $0.081^{* *}$ & 0.041 & -0.020 & 0.784 \\
Developing & $0.132^{* * *}$ & 0.032 & $0.147^{* *}$ & 0.059 & $0.126 * *$ & 0.050 \\
\hline
\end{tabular}

Standard errors in parentheses and computed with Delta method $* * * \mathrm{p}<0.01, * * \mathrm{p}<0.05, * \mathrm{p}<0.1$

Figure 1. R\&D investment positively moderates the innovation effects of Deped_ODI

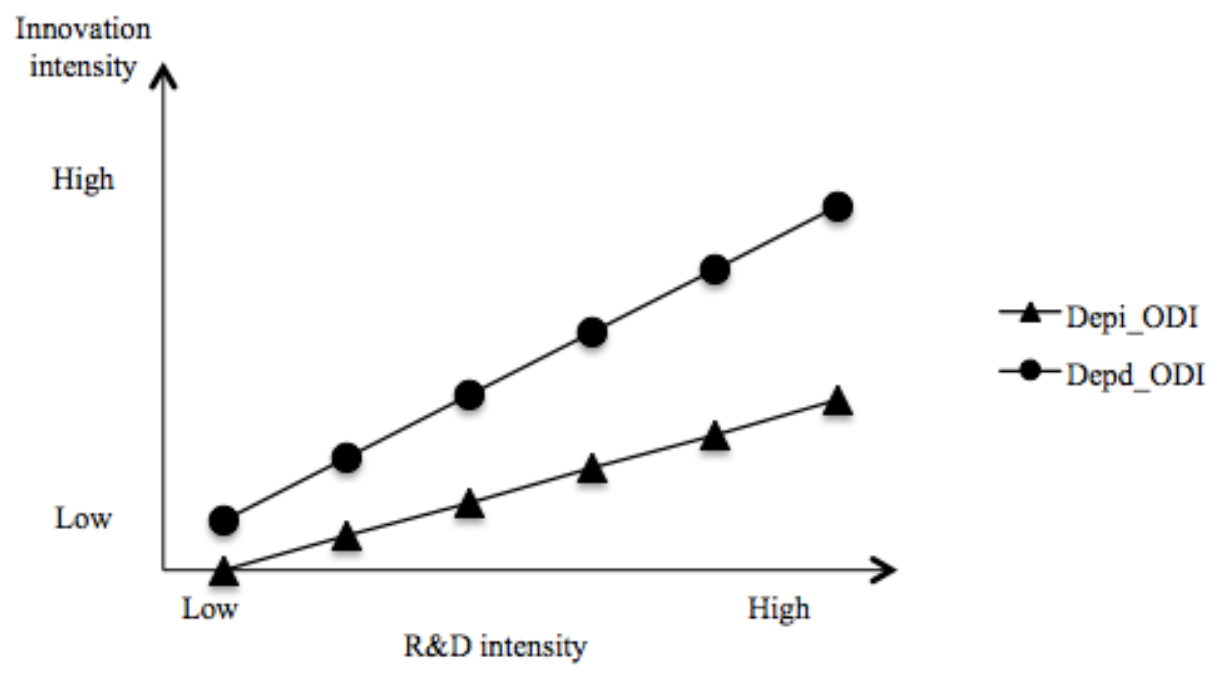

The moderating effects between ODI, R\&D expenditure, investment motives and exporting experience are captured by the interaction terms in Model 1, Model 2 and Model 3 (Table 3). The estimates of Depd_ODI*R\&D are negative at a 0.01 significance level, in particular for the high-tech firms which show the lowest magnitude, -0.115. Investment motives and exporting experience display positive moderating effects on the relationship between ODI conducted in developed countries and innovation performance. Nevertheless, these effects only appear in the sample of high-tech firms, while the estimates for the low-tech group are positive but not statistically significant. 


\section{Robustness check $^{13}$}

Although the random methodology has taken into account the potential bias introduced by random components in the errors, the possible endogeneity induced by the unobserved factors existing in the error term may also cause inconsistencies. We employed the fixed effect method to correct the endogenous bias caused by the time-invariants. After deriving the mean deviations of variables to be estimated, observed time-invariants such as SOEs and Hi-tech are cancelled out in the objective function. Attempting to control the lagged impacts of R\&D and ODI on innovation, estimation of the full sample is conducted with one year lagged explanatory variables including R\&D, EXP, Depd_ODI, and Depi_DOI. Including a one-year lag has resulted in losing another wave of the sample, there were 379 observations and the number of firms remains unchanged at 189.

Table 5. Robustness check: fixed effects' estimation at the mean (same specification as Model 4 in Table 3) and estimation with one-year lagged values

\begin{tabular}{|c|c|c|c|c|c|c|c|c|}
\hline & \multicolumn{2}{|c|}{ Full } & \multicolumn{2}{|c|}{ Hi-tech } & \multicolumn{2}{|c|}{ Low-tech } & \multicolumn{2}{|c|}{ Full_one year lag } \\
\hline & Coef. & $\begin{array}{l}\text { Std. } \\
\text { Err. }\end{array}$ & Coef. & Std. Err. & Coef. & $\begin{array}{l}\text { Std. } \\
\text { Err. }\end{array}$ & Coef. & $\begin{array}{l}\text { Std. } \\
\text { Err. }\end{array}$ \\
\hline $\mathrm{R} \& \mathrm{D}^{14}$ & $0.063 * * *$ & 0.007 & $0.069 * * *$ & $0.063 * * *$ & 0.007 & 0.012 & $0.101 * * *$ & 0.011 \\
\hline Depd_ODI & $0.273^{* *}$ & 0.116 & $0.525^{*}$ & $0.273 * *$ & 0.116 & 0.268 & $0.779 * * *$ & 0.175 \\
\hline Depi_ODI & 0.024 & 0.106 & 0.091 & 0.024 & 0.106 & 0.230 & 0.098 & 0.213 \\
\hline Depd_ODI*R\&D & $-0.042 * * *$ & 0.014 & $-0.075^{* *}$ & $-0.042 * * *$ & 0.014 & 0.032 & $-0.090 * * *$ & 0.025 \\
\hline Depi_ODI*R\&D & -0.008 & 0.014 & -0.049 & -0.008 & 0.014 & 0.036 & -0.040 & 0.044 \\
\hline Depd_ODI*Exp & -0.173 & 0.763 & -0.631 & -0.173 & 0.763 & 2.248 & 1.785 & 2.108 \\
\hline Depi_ODI*Exp & -0.823 & 1.424 & 0.031 & -0.823 & 1.424 & 2.692 & 0.746 & 8.442 \\
\hline Depd_ODI*Tech & $0.219 * *$ & 0.094 & 0.084 & $0.219 * *$ & 0.094 & 0.159 & $0.429 * *$ & 0.181 \\
\hline Depi_ODI*Tech & 0.042 & 0.116 & 0.378 & 0.042 & 0.116 & 0.306 & -0.486 & 0.349 \\
\hline \multicolumn{9}{|l|}{ Marginal effects } \\
\hline$R \& D$ & $0.059 * * *$ & 0.006 & $0.055^{* * *}$ & $0.059 * * *$ & 0.006 & 0.011 & $0.032 * * *$ & 0.004 \\
\hline Export & 0.044 & 0.133 & -0.052 & 0.044 & 0.133 & 0.498 & -0.041 & 0.190 \\
\hline Tech & $0.021 * *$ & 0.010 & 0.039 & $0.021 * *$ & 0.010 & 0.030 & 0.013 & 0.024 \\
\hline Developed & $0.217 * * *$ & 0.070 & 0.219 & $0.217 * * *$ & 0.070 & 0.175 & $0.143 * * *$ & 0.048 \\
\hline Developing & -0.046 & 0.098 & 0.080 & -0.046 & 0.098 & 0.120 & 0.021 & 0.223 \\
\hline Observations & \multicolumn{2}{|c|}{567} & \multicolumn{2}{|c|}{198} & \multicolumn{2}{|c|}{369} & \multicolumn{2}{|c|}{379} \\
\hline Number of firms & \multicolumn{2}{|c|}{189} & \multicolumn{2}{|c|}{66} & \multicolumn{2}{|c|}{123} & \multicolumn{2}{|c|}{189} \\
\hline
\end{tabular}

Standard errors in parentheses and computed with Delta method $* * * \mathrm{p}<0.01, * * \mathrm{p}<0.05, * \mathrm{p}<0.1$

\footnotetext{
${ }^{13}$ Fixed effects' estimations are computed based on Model 5 in Table 5 which model is this?.

${ }^{14}$ Marginal effects of R\&D here are calculated without taking into account the interaction terms.
} 
The first seven columns on the left of Table 5 tabulate the estimation results of controlling for the individual fixed components, which is equivalent to removing $\omega_{i}$ in equation (2). The last two columns are estimators from one-year lagged estimation. The upper panel gives the estimation coefficients of the main variables and the panel below presents the marginal effects which are computed by considering the presence of moderating effects. In general, the results generated from fixed effects are consistent with those of the Random Tobit models. The only difference is that the focal firm's international experience no longer appears to influence innovation performance, neither does it perform as a moderator for ODI. One possible explanation attributes this to the limited variation of the mean deviation that has been used in the fixed effects specification, which as a consequence could reduce the explanatory power of variables.

\section{Discussion and conclusion}

Adopting a learning approach, we examine the impact of ODI undertaken by Chinese firms and the contingent effects of firm characteristics and external factors on the relationship between ODI and innovation performance, based on a panel data analysis of a sample of Chinese firms. Our findings show that ODI in developed countries, as an external learning channel, positively affects Chinese firms' innovation performance. Such a positive impact is enhanced by the focal firm's international experience and the knowledge-seeking orientation. Our research also finds that ODI in developed countries is used as a substitute for in-house $R \& D$ in these Chinese firms. This suggests that ODI replaces in-house R\&D and serves as an innovation-seeking strategy through acquiring external knowledge in advanced host countries. Below we highlight a number of important findings which help advance our understandings of ODI from EEs.

The role of ODI in explaining innovation: do host countries matter?

Our findings suggest that when adopted as a catch up strategy, ODI in developed countries enables Chinese firms to acquire advanced know-how and reinforce their innovativeness. Hostcountry locations matter as they provide a variety of external knowledge for CMNEs to learn. By directly operating in developed countries through ODI, CMNEs can gain the proximity advantages that help them establish various linkages with technology leaders. Proximity to 
technological leaders also allows CMNEs to absorb the locally embedded technological advances, managerial competences and invaluable skills that are otherwise not available in their home market. Consistent with previous studies (e.g. Lane and Lubatkin, 1998), our results indicate that countries with innovation advantages measured by higher R\&D in GDP ratio are able to provide the technological needs of CMNEs (Deng, 2012; Lane and Lubatkin, 1998; Lu et al., 2011; Luo and Tung, 2007; Rui and Yip, 2008). By synthesising host countries' resources with those inherited from their home country, CMNEs configure ODI activity as a learning mechanism through which international knowledge assets are exploited and assimilated.

Our finding also indicates that the positive innovation-enhancing effect of undertaking ODI in developed countries is achieved through multiple channels. Engaging in the value chains in a host country has helped CMNEs accumulate market knowledge to overcome the liability of foreignness that would eventually facilitate the extent and speed of cross-border knowledge flows. Meanwhile, the physical presence of CMNEs in a foreign market encourages them to gain better understanding about the customer preference, thus facilitating the introduction of host-market-friendly new products. Another channel through which ODI in developed countries fosters innovation can be attributed to the market mechanism in the host country. The competitive market environment and high quality standards in advanced economies force CMNEs to exert continuous efforts to innovate and upgrade their technological capabilities. In this regard, ODI in developed countries has, at least from the supply side, provided a knowledge-rich platform for CMNEs to catch up with technological leaders.

\section{Strategic orientations and Chinese firms' pathway to innovation}

The empirical evidence shows that Chinese firms with knowledge-seeking orientation perform better in new product sales compared to those without. The intention of exploring knowledge assets through cross-border investment has enabled Chinese firms to acquire more advanced technology and thus boosts innovation. With an explicit technology-exploration purpose, firms are likely to be more proactive in knowledge learning, deploying resources, and thereby induce a higher level of innovation performance than firms with other motives. A clear and strong technology-oriented motive therefore is necessary to achieve the strategic objective of innovation-springboard ODI.

Moreover, the finding suggests that strategic orientation serves as an important internal condition affecting the effectiveness of ODI location on innovation performance. Firms with 
strong knowledge-seeking orientation are associated with high levels of willingness to learn external knowledge (Deng, 2009; Lu et al., 2011), and thus such motivation tends to further strengthen the positive association between ODI in developed countries and their innovation performance.

\section{$R \& D$ and $O D I$ in different industries: is there a substitution?}

Although both factors have directly contributed to new product sales, R\&D expenditures also interact with ODI and indirectly affect innovation performance. This is different from findings from the literature in the context of MNEs from developed countries. The results indicate that a high level of ODI in developed countries substitutes for in-house $R \& D$, thus reducing the importance of the focal firm's in-house R\&D in innovation performance. The finding implies that Chinese firms use ODI in developed countries as an alternative source of in-house R\&D through acquiring foreign technology assets (Fu, 2012). There is a trade-off between undertaking ODI in developed countries and conducting in-house R\&D. Our findings suggest a substitution effect between ODI and in-house R\&D in EMNEs, instead of the complementarity between these two factors. This may be partly because in the context of China, during the sample period, 'create' or 'buy' are two often compared alternative innovation strategies for the latecomer firms (Cassiman and Veugelers, 2006). On the one hand, limited resources for innovation and the hard budget constraints for the non-state-owned firms make them choose one of the two alternative strategies. On the other hand, organisation rigidities and the 'not invented here' syndrome make these firms go for either 'create' or 'buy'. Moreover, although R\&D is regarded as a two-edged sword serving as a source for both knowledge creation and absorptive capacity development (Cohen and Levinthal, 1989; Lokshin et al., 2008), in the literature education and training play a more important role in the development of absorptive capacity than does R\&D (eg. Kneller and Stevens, 2006), especially in the developing countries including China. Therefore, we observe that most CMNEs are more likely to use ODI in developed countries as an alternative channel or even as a short-cut for technical upgrading and leapfrogging.

Such a substitution effect is more pronounced in high-tech industries than low-tech ones. This implies that the dynamic nature of high-tech industries, and the technology gaps between EEs and developed countries, requires Chinese firms to use ODI as an effective channel to overcome internal resource constraints. Chinese followers in these industries have to shoulder 
high risks and uncertainties and therefore transferring foreign knowledge into local use becomes costly (Amadbile, 1997). With the presence of hard budget constraints, undertaking ODI as a source of knowledge acquisition would lead to the decrease of limited resources allocated to traditional innovation practices such as in-house R\&D. Hence, the substitute effect between ODI and R\&D is higher in high-tech sectors than in low-tech ones. In the latter, CMNEs are allowed to neutralize the competitive advantages of the leader because the technology gap is smaller and technological contents are less costly than in high-tech industries. This explains why the substitute effect of R\&D is lower for low-tech sector firms.

Previous exporting experience and learning outcome: firms with prior export experiences gain more from $O D I$

A complementary relationship between prior international experience and ODI is observed. With a series of constraints such as cultural differences, adaptation difficulties and capacity limits, Chinese firms need to firstly gain international experiences to ensure the success of foreign operations. Prior exporting experiences have equipped Chinese firms with the necessary abilities to overcome the potential barriers to knowledge acquisition via ODI. In line with previous studies (Wagner, 2007; Ito and Wakasugi, 2007), exporting experiences help Chinese firms accumulate adequate international experience that ensures successfully entering an international market and competing with foreign rivals. Previous international experience enhances the positive impact of ODI investing in developed countries. As another form of external learning, exporting strengthens the breadth and depth of subsidiary networks that in turn help them to overcome potential cross-border investment barriers. The more the Chinese firm is engaged in the global value chain, the more likely it is to better identify, assimilate and integrate the knowledge flowing via ODI, thus reinforcing the positive impact of ODI on innovation. In addition, it is observed that the complementary effect between ODI and export intensity is more profound for Chinese firms in a high-tech industry where tacit knowledge constitutes a crucial element of core technology.

Our study contributes to the existing literature in three main ways. First, focusing on the role of ODI by CMNEs in innovation, our study provides theoretical rationale and empirical evidence on the innovation-enhancing effect of ODI from the learning perspective. In doing so, our research sheds light onto external learning via ODI in the context of technological catch up 
of emerging economies and enhances our understanding of the importance of external knowledge sourcing in fostering the innovation capability of EE firms.

Second, differing from most prior studies in this area, our study moves beyond the direct link between ODI and innovation performance by identifying the boundary conditions under which ODI affects innovation performance. In particular, we take account of the role of contextual factors in the relationship between ODI and the innovation performance of CMNEs. While ODI has been widely acknowledged as a means of international knowledge acquisition in the existing literature (Luo and Tung, 2007; Deng, 2009; Liu and Giroud, 2016), most studies tend to assume that the innovation-enhancing effect of ODI is homogenous regardless of investment destinations and industry context. This assumption limits our understanding of conditions under which external learning is effective. Thus, it is theoretically and empirically important to specify the contingency conditions which either enhance or hinder the link between ODI and innovation. Our research not only demonstrates ODI as a learning channel for EMNEs, but also goes a step further by identifying where to learn or acquire external knowledge.

Finally, our findings reveal that there is a complementary effect between different forms of external learning, such as learning through exporting and learning through ODI, whereas external learning via ODI substitutes for internal learning, such as conducting in-house R\&D. By considering the interaction effect between ODI and in-house $\& \& D$, this study captures the tension between external learning and internal learning, showing that EMNEs engage in external learning through ODI in order to compensate for the lack of advanced technology. However, this type of learning is resource intensive, and thus results in fewer resources to be allocated to internal learning via in-house $R \& D$. It also shows that absorptive capacity through internal knowledge accumulation is less compatible with external learning. This finding enriches our understanding of the barriers to knowledge acquisition and creation. While the existing literature has documented that large technological gaps and low levels of absorptive capacity of EE firms constitute barriers to external knowledge acquisition and utilization (Deng, 2009; Liu and Buck, 2009; Zhang et al., 2010), it pays little attention to resource constraints and compatibility of internal and external knowledge. Our findings suggest that EE firms encounter more barriers when involved in various forms of learning. These barriers complicate the learning process, making learning a less straight forward activity. Thus, our research extends organisational learning theory by providing a more complete account of EMNEs' learning. 


\section{Implications}

The findings of our research provide important implications for EE policy makers. In directing firms to acquire advanced technology from developed countries, governments in EEs should adopt policy instruments to develop an effective reverse knowledge transfer platform that jointly considers several critical aspects such as MNEs' characteristics, host market environment, and industrial context. In comparison to EEs, the large and rich knowledge pools in developed countries in general offer better opportunities for EE firms to acquire advanced technologies, if learning takes place in the industries where the EE firms have already built up competitiveness. Hence, policies need to be more fine-grained in terms of the countries and industries in which EE firms are able to boost innovation through ODI. Despite the differences between China and other EEs, they share some common features with other middle income developing countries. In particular, their firms are also latecomers which need to catch up with the technological leaders in developed countries. Conducting ODI in developed countries can be adopted as an effective pathway for these latecomer firms, in particular from high-tech sectors, to move up to the technology frontier. Thus, the implications from our study are not only relevant to China, but also to other EEs. Nevertheless, caution should also be preserved in the simple replication of China's experience because of important differences between China and the other EEs in enterprise ownership structure and in government policy (or lack of it) towards ODI.

From a managerial perspective, the strength of this research lies in helping MNEs originally from emerging countries to better understand the moderating factors influencing the crossborder technology flows. In particular, our findings help managers of EE MNEs understand the conditions necessary to achieve knowledge exploration motives and show that investment destinations and industry context are important contingency factors for latecomers to catch up through engaging ODI. Hence, managers should carefully evaluate contextual factors when making investment decisions.

\section{Limitations}

Given the fact that the current research is based on a short panel covering only three years, the lag impacts of R\&D and ODI on innovation cannot be fully controlled efficiently. A longer period panel would be more ideal to conduct estimations to address this issue. A dynamic analysis could also be used in investigating the relationship between ODI and innovation 
performance, taking into account the path-dependent nature of the innovation process if extra data sources are available. Another constraint of the current study lies in the limited number of ODI firms in the sample, especially those conducting investment in developing countries. It is also found that the sample CMNEs invest in either developed or developing countries. Therefore, we have not been able to cover CMNEs that carry out investment in both developed and developing countries. Including firms with geographically broader investment behaviours would allow us to provide more comprehensive insights for policy implications. In addition, while we have examined the relationship between domestic R\&D and ODI, we are unable to test the direct link between overseas $R \& D$ and domestic $R \& D$ due to the data availability. Future research should investigate this important issue based on qualitative analysis by delineating the nature of substitution between the two types of R\&D investments, as well as the mechanisms of the substitution between in-house R\&D and OFDI. Relatedly, this study has mainly investigated the relationship between domestic R\&D and ODI. Future research may explore whether there is a substitution relationship between technology transfer through foreign joint ventures in China and ODI. Differences between ODI from China and other emergingmarket economies are another area that may produce fruitful insights for us to fully understand the relationship between ODI and innovation in EMNEs. Finally, we have mainly focused on whether the knowledge seeking motive has a stronger moderating effect than other investment motives on the relationship between ODI and innovation performance. However, resourceseeking and efficiency-seeking are also important motives for Chinese ODI. It is important to examine whether EMNEs with the two motives are also able to enhance their innovation performance. 


\section{References}

Amadbile, T. M., 1997. Motivating Creativity in Organizations: on Doing what You Love and Loving what You Do. California Management Review 40 (1), 39-58.

Athreye, S., 2005. The Indian software industry and its evolving service capability. Industrial and Corporate Change 14 (3), 393-418.

Blonigen, B. \& Taylor, C., 2000. R\&D intensity and acquisitions in high-technology industries: evidence from the U.S. electronic and electrical equipment industries. Journal of Industrial Economics 48, 47-70.

Boisot M. \& Meyer M. W., 2008. Which way through the open door? Reflections on the internationalization of Chinese firms. Management Organization Review 4 (3), 349-365.

Buckley, P. J., Clegg, L. J., Cross, A.R. \& Liu, X., 2007. The Determinants of Chinese outward foreign direct investment. Journal of International Business Studies 38, 499-518.

Burghart, N. \& Rossi, V., 2009. China's overseas direct investment in the UK. Chatham House, London.

Cantwell, J., 1989. Technological Innovation and Multinational Corporations. Blackwell, Oxford.

Cantwell, J. \& Jane O., 1999. Technological Globalization and the Innovative Centres: The Role of Corporate Technological Leadership and Locational Hierarchy. Research Policy 28 (2-3), 119-44.

Cassiman, B. \& Veugelers R., 2006. In Search of Complementarity in the Innovation Strategy: Internal R\&D and External Knowledge Acquisition. Management Science 52, 68-82.

Chari, A., Chen W. \& Domingues, K. 2012. Foreign ownership and firm performance: emerging market acquisitions in the United States. IMF Economic Review 60 (1), 1-42.

Chen, W. \& Tang, H., 2016. The dragon is flying west: micro-level evidence of Chinese outward direct investment. Asian Development Review 31 (2), 109-140.

Chesbrough, H., 2003. Open Innovation: The New Imperative for Creating and Profiting from Technology. Harvard Business School Publishing, Boston, MA.

Chesbrough, H., \& Crowther, A. K., 2006. Beyond high tech: early adopters of open innovation in other industries. $R \&$ D Management 36(3), 229-236.

Child, J. \& Rodrigues, S.B., 2005. The internationalization of Chinese firms: A case for theoretical extension? Management and Organization Review 1 (3), 381-410.

Chudnovsky, D., López, A. \& Pupato, G., 2006. Innovation and productivity in developing countries: A study of Argentine manufacturing firms' behavior (1992- 2001). Research Policy 35 (2), 266288.

Cohen, W. M. \& Levinthal, D. A., 1989. Innovation and Learning: The Two Faces of R\&D. The Economic Journal 99, 569-596.

Cozza, C., Rabellotti, R. and Sanfilippo, M., 2013. The impact of outward FDI on the performance of Chinese firms. China Economic Review 36, 42-57.

Crépon, B., E. Duguet and I. Kabla 1996. Schumpeterian Conjectures: A Moderate Support from Various Innovation Measures, in Determinants of Innovation. The Message from New Indicators, A. Kleinknecht (ed.). Macmillan Press, London, 63-98.

Cui, J. \& Jiang, F., 2012. State ownership effect on firms' FDI ownership decisions under institutional pressure: A study of Chinese outward-investing firms. Journal of International Business Studies $43,1-21$.

Cui, L., Meyer, K. E. \& Hu, H., 2013. Who is seeking strategic assets through FDI? A competitive catch-up perspective of emerging economy firms. Journal of World Business 49 (4), 488-501.

Dahlander, L., \& Gann, D. M., 2010. How open is innovation? Research Policy 39(6), 699- 709.

De Clercq, D., Sapienza, H. J., Yavuz, R. I. \& Zhou, L. 2012. Learning and knowledge in early internationalization research: Past accomplishments and future directions. Journal of Business Venturing 27, 143-165.

De Clercq, D., Sapienza, H. J. \& Crijns, H., 2005. The internationalization of small and medium-sized firms: the role of organizational learning effort and entrepreneurial orientation. Small Business Economics 24, 409-419.

Deng, P., 2012. The internationalization of Chinese firms: A critical review and future research. International Journal of Management Reviews 14 (4), 408-427. 
Deng P., 2009. Why do Chinese firms tend to acquire strategic assets in international expansion? Journal of World Business 44, 74-84.

Deng, P., 2007. Investing for strategic resources and its rationale: The case of outward FDI from Chinese companies. Business Horizons 50, 71-81.

Dhanaraj, C. Lyles, M.A., Steensma H.K. and Tihanyi, L. 2004. Managing tacit and explicit knowledge transfer in IJVs: the role of relational embeddedness and the impact on performance, Journal of International Business Studies, 35: 428-42.

Dosi, G., 1988. The nature of the innovation process. In Technical Change and Economic Theory. G. Dosi, C. Freeman, R. Nelson, G. Silverberg \& L. Soete (eds.). Pinter, London/New York, NY.

Driffield, N. \& Love, J. H., 2007. Linking FDI motivation and host economy productivity effects: Conceptual and empirical analysis. Journal of International Business Studies 38 (3), 460-473.

Dunning, J. H. \& Narula, R., 1996. Foreign Direct Investment and Governments. Routledge, London, UK.

Dunning, J. H., 1988. Explaining International Production. Unwin Hyman, London.

Dunning, J. H., 1980. Toward an eclectic theory of international production: some empirical tests. Journal of International Business Studies 11 (1), 9-31.

Fagerberg, J., 2005. Innovation: A guide to the literature. In The Oxford Handbook of Innovation, J. Fagerberg, D .C. Mowery and R. R. Nelson(eds.). Oxford University Press, Oxford and New York.

$\mathrm{Fu}, \mathrm{X}$., 2015. China's Path to Innovation. Cambridge University Press, Cambridge.

Fu, X., 2012. Foreign Direct Investment and Managerial Knowledge Spillovers through the Diffusion of Management Practices. Journal of Management Studies 49 (5), 970-999.

Fu, X., 2011. Processing-trade, FDI and Exports of Indigenous Firms: Firm-level Evidence from Hightechnology Industries in China. Oxford Bulletin of Economics and Statistics 73 (6), 792-817.

Furman, J., Porter, M. .E \& Stern, S., 2002. The determinants of national innovative capacity. Research Policy 31 (6), 899-933.

Gao, G., Pan, Y., Lu, J. \& Tao, Z., 2008. Performance of Multinational Firms' Subsidiaries: Influences of Cumulative Experience, Management International Review 48 (6), 749-768.

Ghauri, P. \& Park, I., 2012. The impact of turbulent events on knowledge acquisition: comparison of cross-border acquisitions formed before and after the crisis. Management International Review 52, 293-315.

Greene, W., 2003. Econometric Analysis. 5th ed. Upper Saddle River, NJ: Prentice-Hall.

Greenaway, D. \& Milner, C., 1990. South-South Trade: Theory, Evidence, and Policy. The World Bank Research Observer 5 (1), 47-68.

Griffith, R., E. Huergo, J. Mairesse, and B. Peters. 2006. Innovation and Productivity Across Four European Countries. Oxford Review of Economic Policy, 22(4), 483-98.

$\mathrm{Gu}$, L. \& Reed, W. R. 2013. Information asymmetry, market segmentation, and cross-listing: Implications for event study methodology, Journal of Asian Economics 28, 28-40.

Howells, J., James, A., Malik, K., 2004. Sourcing external technological knowledge: a decision support framework for firms, International Journal of Technology Management, 27, 143-155.

Hou, J. \& Mohnen, P., 2013. Complementarity between in-house R\&D and technology purchasing: evidence from Chinese manufacturing firms. Oxford Development Studies 41 (3), 343-371.

Huber, G. P., 1991. Organizational learning: the contributing processes and the literatures. Organization Science 2 (1), 88-115.

Hurley, R. \& Hult, T., 1998. Innovation, market orientation, and organizational learning: An integration and empirical examination Journal of Marketing 62 (3), 42-54.

Ito, B. \& Wakasugi, R., 2007. What factors determine the mode of overseas R\&D by multinationals? Empirical evidence. Research Policy 36 (5), 1275-1287.

Javorcik, B. S., 2004. Does foreign direct investment increase the productivity of domestic firms? In search of spillovers through backward linkages. American Economic Review 94, 605-627.

Jerez-Gomez, P., Cespedes-Lorente, J. \& Valle-Cabrera, J., 2005. Organizational learning capability: a proposal for measurement. Journal of Business Research 56 (6), 715-725.

Johanson, J. \& Vahlne, J.-E., 1977. The internationalization process if the firm - a model of knowledge development and increasing foreign market commitments. Journal of International Business Studies 8, 23-32. 
Johanson, J. \& Vahlne, J.-E. 1990. The mechanism of internationalisation. International Marketing Review 7 (4), 111-124.

Kafouros, M, I., Buckley, P. J. \& Clegg. J., 2012. The effects of global knowledge reservoirs on the productivity of multinational enterprises: The role of international depth and breadth. Research Policy 41, 848-861.

Katrak, H., 1997. Developing countries' imports of technology, in-house technological capabilities and efforts: an analysis of the Indian experience. Journal of Development Economics 53(1), 67-83.

Keller, W., 1997. International Technology Diffusion. Journal of Economic Literature 42 (3), 752-782.

Kneller, R. and Stevens, P. A. (2006). 'Frontier technology and absorptive capacity: Evidence from OECD manufacturing industries', Oxford Bulletin of Economics and Statistics, Vol. 68, pp. 1-21.

Kim, L., 1998. Crisis construction and organizational learning: capability building in catching-up at Hyundai Motor Corporation. Organization Science 9 (4), 506-521.

Kokko, A., 1992. Foreign direct investment, host country characteristics and spillovers. Doctoral Dissertation, Stockholm School of Economics.

Kuemmerle, W. T. J., 1997. Building effective R\&D capabilities abroad. Harvard Business Review 75, 61-70.

Lall, S., 1989. Learning to Industrialise: The Acquisition of Technological Capability by India. Macmillan, London.

Lall, S., 1992. Technological Capabilities and Industrialization. World Development 20, 165-186.

Lane, P. J. \& Lubatkin, M., 1998. Relative absorptive capacity and interorganizational learning. Strategic Management Journal 19, 461-477.

Levitt, B. \& March, J. G., 1996. Organizational learning. In M.D. Cohen and L.S. Sproull (Eds.) Organizational Learning. Thousand Oaks, CA: Sage.

Levitt, B. \& March, J. G., 1988. Organisational Learning. Annual Review of Sociology 14, 319-340.

$\mathrm{Li}, \mathrm{P} ., 2007$, Toward an integrated theory of multinational evolution: The evidence of Chinese multinational enterprises as latecomers. Journal of International Management 13, 296-318.

Liu, C-L., Ghauri, P. \& Sinkovics, R., 2010. Understanding the impact of relational capital and organisational learning on alliance outcomes. Journal of World Business 45, 237-249.

Liu, X., \& Buck, T. 2009. The Internationalization of Chinese firms: Two case studies from Lenovo and BOE. Journal of Chinese Economic and Business Studies 7 (3), 167-181.

Liu, X., Buck, T. \& Shu, C., 2005. Chinese economic development, the next stage: outward FDI?. International Business Review 14 (1), 97-115.

Liu, X. \& Giroud, A., 2016. International knowledge flows in the context of emerging economy MNEs and increasing global mobility. International Business Review 25 (1), 125-129.

Lokshin, B., R. Belderbos and M. Carree 2008. The Productivity Effects of Internal and External R\&D: Evidence from a Dynamic Panel Data Model. Oxford Bulletin of Economics and Statistics 70(3):399-413.

Lu, J., Liu, X. \& Wang, H., 2011. Motives for outward FDI of Chinese private firms: Firm Resources, industry dynamics, and government policies. Management and Organization Review 7 (2), 223248.

Lu, J., Liu, X., Wright, M. \& Filatotchev, I., 2014. FDI Location Choices of Chinese Firms: The Moderating Effects of Home Country Government Support and Host Country Institutions on Internationalization Experience. Journal of International Business Studies 45 (4), 428-449.

Luo, Y. \& Tung, R., 2007. International expansion of emerging market enterprises: A springboard perspective. Journal of International Business Studies 38 (4), 481-498.

Luo, L., \& Wang, L. 2012. Foreign direct investment strategy by developing country multinationals: A diagnostic model for home country effects. Global Strategy Journal 2, 244-261.

Lyles, M. A. \& Dhanaraj, C., 2004. Organizational learning and international alliances. In Mahnke, V. and Pedersen, T. (Eds.), Knowledge Flows, Governance and the Multinational Enterprise. Palgrave McMillan, New York.

Maddala, G. S., 1987. Limited Dependent Variable Models Using Panel Data. Journal of Human Resources 22 (3), 307-338.

Mairesse, J., and P. Mohnen. 2002. Accounting for Innovation and Measuring Innovativeness: An Illustrative Framework and an Application. American Economic Review, 92(2), 226-30. 
Makino, S. \& Lau, C. M., 1998. The road to MNE of firms from newly industrialized economies. Paper presented at the Academy of Management annual meetings, San Diego.

Marin, A. \& Bell, M., 2010. The local/global integration of MNC subsidiaries and their technological behaviour: Argentina in the late 1990s. Research Policy 39 (7), 919-931.

Mathews, J. A., 2006. Dragon multinationals: New players in 21st century globalization. Asia Pacific Journal of Management 23, 5-27.

Meyer, K., Wright, M. \& Pruthi, S., 2009. Managing knowledge in foreign market entry strategies: a resource based analysis. Strategic Management Journal 30, 557-574.

Morck, R., Yeung. B. \& Zhao, M., 2008. Perspectives on China's Outward Foreign Direct Investment. Journal of International Business Studies 39 (3), 337-350.

Mowery, D. \& Oxley, J.,1995. Inward technology transfer and competitiveness: the role of national innovation system. Cambridge Journal of Economics 19 (1), 67-93.

Muehlfeld, K., Sahib, P. R. \& Van Witteloostuijn, A., 2012. A contextual theory of organisational failures and successes. A study of the acquisition completion in the global newspaper industry 1981-2008. Strategic management Journal 33 (8), 938-964.

Narula, R., 1996, Multinational Investment and Economic Structure. Routledge, London,

Narula, R. \& Santangelo, G., 2009. Location, collocation and R\&D alliances in the European ICT industry. Research Policy 38, 393-403.

Nelson, R. R. \& Winter, S. G., 1982. An Evolutionary Theory of Economic Change. Belknap Press/Harvard University Press, Cambridge.

Niosi J., 1999. The internationalization of industrial R\&D: from technology transfer to the learning organization. Research Policy 28, 107-17.

Pavitt, K., 2005. Innovation Processes. In J. Fagerberg, D. C. Movery,\& R. R. Nelson (eds.), The Oxford Handbook of Innovation: 86-114. Oxford University Press, Oxford.

Pearce R. D., 1999. Decentralised R\&D and strategic competitiveness: globalised approaches to generation and use of technology in multinational enterprises (MNEs). Research Policy 28, 157178.

Peng, M.W., 2012. The global strategy of emerging multinationals from China . Global Strategy Journal 2 (2), 97-107.

Pittiglio, R., Sica, E. \& Villa, S., 2009. Innovation and internationalization: the case of Italy. Journal of Technology Transfer 34, 588-602.

Polanyi, M., 1966. The logic of tacit inference. Philosophy, 41, 1-18.

Polanyi, M., 1967. The Tacit Dimension. London: Routledge.

Ramamurthi, R. \& Singh, J. V., 2009. Emerging Multinationals in Emerging Markets. University Press, Cambridge.

Reuber, A. R. \& Fischer, E., 1997. The Influence of the Management Team's International Experience on the Internationalization Behavior of SMEs. Journal of International Business Studies 28 (4), 807-825.

Rui, H. \& Yip, G. S., 2008. Foreign acquisitions by Chinese firms: A strategic intent perspective. Journal of World Business 43, 213-226.

Sachwald, F., 2001. Going Multinational: The Korean Experience of Direct Investment Routledge , London.

Senker, J., 1993. The contribution of tacit knowledge to innovation. AI \& Society, 7 (3), 208-24.

Sun, S.L., Peng, M. W., Ren, B. \& Yan, D., 2010. A comparative ownership advantage framework for cross-border M\&As: The rise of Chinese and Indian MNEs, Journal of World Business 47, 1, 416.

Takeuchi, R., Tesluk., P. E., Yun, S. \& Lepak, D. P., 2005. An integrative view of international experience. Academy of Management Journal 48, 85-100.

Teece, D. J., Pisano, G. \& Shuen, A., 1997. Dynamic Capabilities and Strategic Management. Strategic Management Journal 18 (7), 509-533.

Uzzi, B., 1997. Social Structure and Competition in Interfirm Networks: The Paradox of Embeddedness, Administrative Science Quarterly 42, 35-67.

Veugelers, R., 1997. Internal R\&D expenditures and external technology sourcing, Research Policy 26(3): 303-315. 
Veugelers, R. and B. Cassiman, 1999. Make and Buy in Innovation Strategies: Evidence from Belgian Manufacturing Firms, Research Policy, 28: 63-80.

Wagner, J., 2007. Exports and productivity: a survey of the evidence from firm-level data. The World Economy 30, 60-82.

Wang, M., 2002. The motivations behind China's government-initiated industrial investments overseas. Pacific Affairs 75, 187-206.

Wang, C., Hong, J., Kafouros, M. \& Wright, M., 2012. Exploring the role of government involvement in outward direct investment from emerging economies. Journal of International Business Studies 43 (7), 655-676.

Witt, A.\& Lewin, Y., 2007. Outward foreign direct investment as escape response to home country constraints. Journal of International Business Studies 38( 4), 579-594.

Zhang, Y., Li, H., Li, Y. \& Zhou, L., 2010. FDI spillovers in an emerging market: The role of foreign firms' country origin diversity and domestic firms' absorptive capacity. Strategic Management Journal 31 (9), 969-989.

Zhang, Z. X., 2014. Energy Prices, Subsidies and Resource Tax Reform in China. Asia \& the Pacific Policy Studies, 1 (3), 439-454.

Zollo, M. \& Winter, S. G., 2002. Deliberate Learning and the Evolution of Dynamic Capabilities. Organization Science 13 (3), 339-351. 